\title{
Role of International Financial Organizations in the Economic Growth of Bangladesh: A Case Study from the Perspective of Project Finance Challenges \& Prospects
}

\author{
Fahmida Ahmed \\ Lecturer, Faculty of Business Administration (FBA), University of Science \& Technology Chittagong (USTC), \\ Chittagong, Bangladesh.
}

\begin{abstract}
Economic growth is one aspect of the process of economic development which shows the increasing capacity of the economy to satisfy the demand of goods and services of the member of the society. International Financial Organizations can play an actives role in this core area of economic development. These organizations support the efforts of the Government of Bangladesh to reduce the poverty and increase the productivity of rural poor people in ways that are both sustainable and environmentally friendly. The study reveals some selected International Financial Organizations are contributes enough to achieve stable growth of the economic through project finance. This paper focuses on the contributions of four major, high-profile organizations: International Bank for Reconstruction and Development (IBRD) and the International Development Association (IDA), Asian Development Bank (ADB) and International Financial Corporation (IFC).

This study also consider the question how project finance can affect economic growth: that leads not only to an increase in the quantity of capital but most importantly also to an improvement in the quality of capital and thus ultimately to economic growth
\end{abstract}

Keywords: International Financial Organizations, Project Finance and Economic growth.

\section{Introduction}

From the precarious beginning, Bangladesh has achieved notable progress in economic and social development in about four decades. When it became independent in 1971 following a bloody war, many were skeptical about the country's long term economic viability. Some observers predicted a state of perennial aid dependence, while others referred to it as a "test case of development" (Faaland and Parkinson 1976), implying that if a country with such gargantuan and myriad of development problems as Bangladesh could make development happen, then perhaps any country could. In the face of low per capita incomes and widespread illiteracy, it has made successful strides toward demographic transition and reduced its population growth rate from 2.5 percent per year in the 1980s to less than 1.5 percent per year in 2005 (Bangladesh Bureau of Statistics 2007b). In a number of other social indicators, such as infant mortality, life expectancy, primary school enrollment, female enrollment in school, and adult literacy, Bangladesh has made considerable improvements over the years. Economic development happens in most places largely because of Project Finance, which seems to be case in Bangladesh as well. Broad-based public \& private sectors led economic growth and stability contributed to different large scale projects. The use of non-recourse project financing has grown steadily in emerging markets, especially in basic infrastructure, natural resources, the energy sector and urban \& rural poverty reduction. International Financial Organization especially IBRD, IDA, IFC and ADB can play a vital role in advancing economic and social enhancement of Bangladesh. They have developed a climate favorable to capital formation. Especially these international financial organizations are contributed in Bangladesh economic growth through Project Finance.. The World Bank and World Bank Groups employing a carefully engineered financing mix through project finance has long been used to fund large scale natural resources projects, pipelines, hydro-electric projects, infrastructural projects and rural \& urban development projects etc.. This study is investigate the role of International Financial Organizations in the Economic Growth of Bangladesh through Project Finance. In this study we provide new insights regarding whether and how financial development can affect economic growth by focusing on one specific financial instrument: project finance. Project finance is designed to reduce of transaction costs, in particular those arising from a lack of information on possible investments and capital allocation, insufficient monitoring and exertion of corporate governance, risk management, and the inability to mobilize and pool savings. Thus, project finance should thus have a clear impact on economic growth. Our empirical analysis of growth in Bangladesh from 2006 to 2011 confirms this 
hypothesis. Project finance by IBRD, IDA, ADB and IFC is a strong driver of economic growth of Bangladesh where transaction costs are particularly high.

\section{Research Questions}

Some of the most important research questions addressed by the study are as follows:

i) How are International Financial Organizations related to the development of the country's economy?

ii) Is investment growth of International Financial Organizations significantly related to the GDP per capita?

iii) Is there any positive relationship between project finance and economic growth?

\section{Objectives of the study}

The main objective of the study is to reveal and access the role of International Financial Organizations in the Economic Growth of Bangladesh from the perspective of project finance. In this regard, the study highlighted four international financial organizations such as IBRD, IDA, IFC and ADB and their large contributions to finance multi projects of Bangladesh.

\section{Methodology of the study}

This research paper is basically desk based research. The literature is mostly taken from the secondary sources such as journals, books, internet, Yearly Economic Survey by the Ministry of Finance, Bangladesh Bureau of Statistics ,Annual Reports of Internationals Financial Organizations etc. Some crucial concepts are issued to support argument concerning specific issues and also as evidence to current practices regarding financing of Projects. The statistical tools namely correlation, regression and growth model have been used for the analysis of collected data.

\section{Overview The role of International financial organizations in Bangladesh}

International financial organizations especially World Bank is a vital sources of financial and technical assistance to developing countries around the world. Actually World Bank are not a bank in the ordinary sense but a unique partnership to reduce poverty and support development. It comprise two institutions managed by 187 member countries: the International Bank for Reconstruction and Development (IBRD) and the International Development Association (IDA). The IBRD aims to reduce poverty in middle-income and creditworthy poorer countries, while IDA focuses exclusively on the world's poorest countries. These institutions are part of a larger body known as the World Bank Group.

The International Bank for Reconstruction and Development (IBRD) have large affect on economic development in Bangladesh by promoting sustainable development through loans, guarantees, risk management products, and analytical and advisory services. It established in 1944 as the original institution of the World Bank

Lending by Volume in Millions of US Dollars - Bangladesh

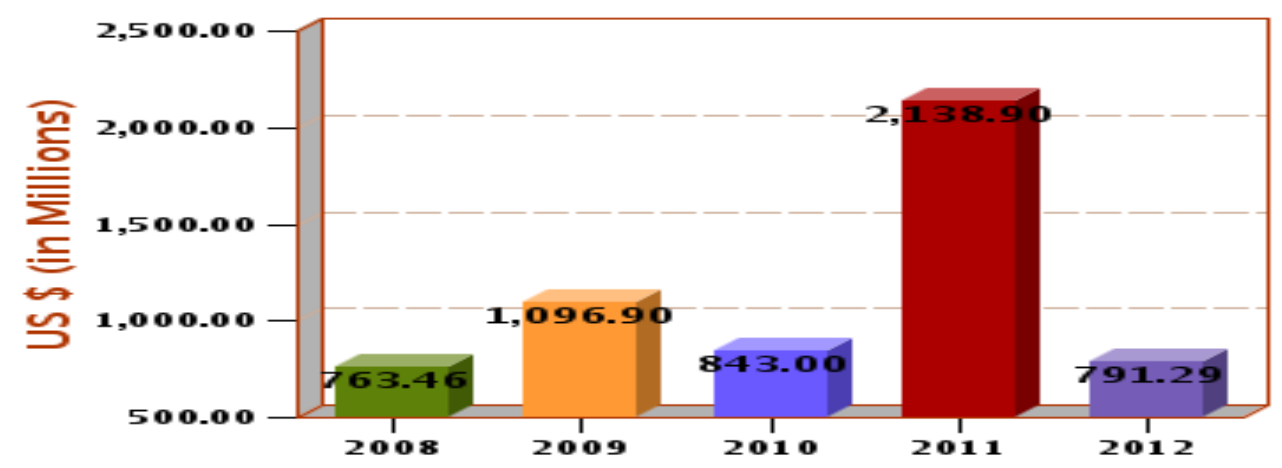

For the current Fiscal Year the chart shows total commitment amount to date. Total lending includes IBRD, IDA, GEF/GEF Medium size/Carbon Offset projects

Lending by Volume in Number of Projects - Bangladesh 


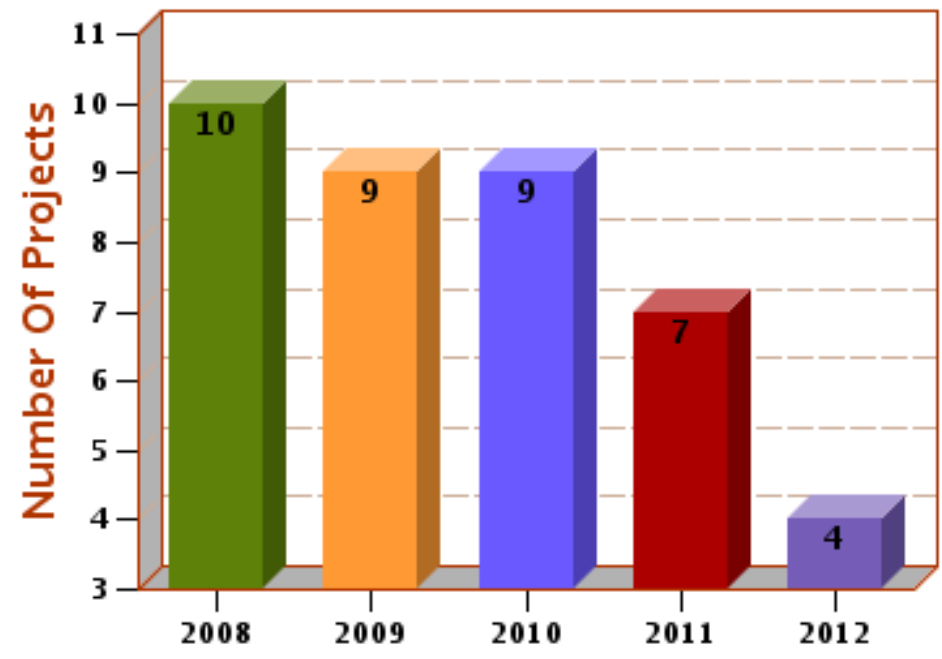

For the current Fiscal Year the chart shows the number of approved projects to date. Data update frequency : monthly

Bangladesh is one of the largest recipients of support from International Development Association (IDA), the World Bank's concessionary arm. Since 1972, the World Bank has committed more than $\$ 15$ billion support to the Government of Bangladesh to reduce poverty and improve the lives of the people. The World Bank works in close partnership with the Government of Bangladesh and always aligns its programs and projects with Government priorities. It also works closely with other development partners, non-government organizations, civil society, academia, and other stakeholders.

All support and projects are developed in close consultation with the government and the people of Bangladesh. The World Bank currently has a portfolio of 27 active projects with a net commitment of $\$ 3.61$ billion. The projects utilize local knowledge and expertise. Several projects have actively involved the local communities in design and implementation. It supports the Government in its efforts on macro-economic stability and growth, power, infrastructure, climate change and disaster management, human and social development and poverty reduction. The World Bank provides both financing and technical assistance that have helped the country to be on track on achieving the MDGs

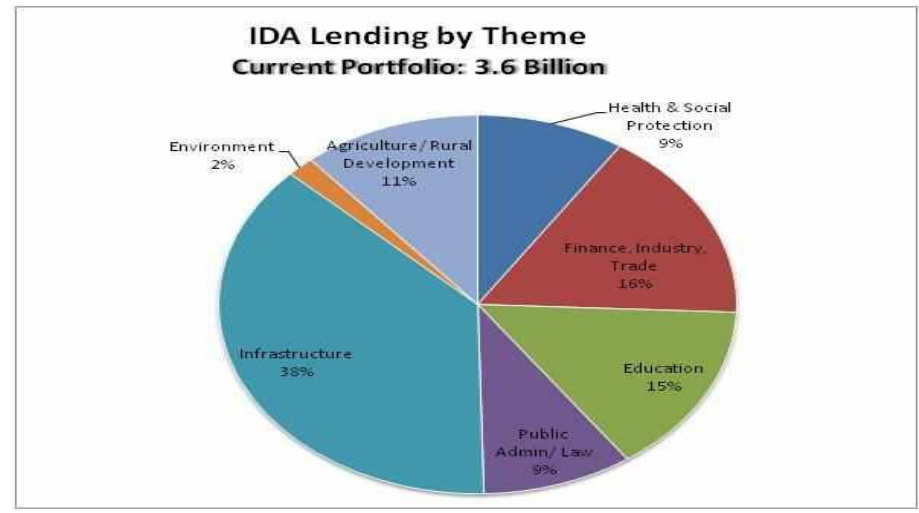

The World Bank has provided concessional lending above $\$ 1$ billion in a single year for the first time in 2009. The same trend is expected to continue. All World Bank loans to Bangladesh are interest free IDA credits, with 10 year grace period and 40 year maturity period. 


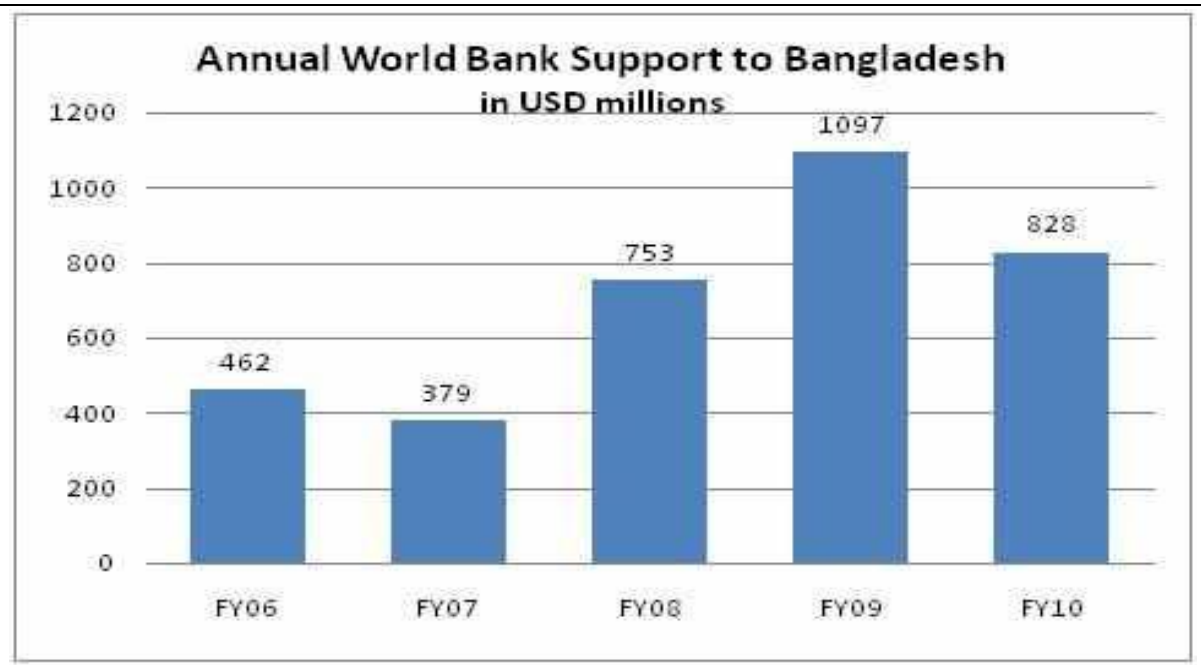

Source: World Bank, 2011, Basic Statistics

Bangladesh joined the Asian Development Bank (ADB) in 1973. Cumulative lending amounts to about $\$ 12.1$ billion for 212 loans, with $\$ 202.7$ million for technical assistance grants for 363 projects. The country is one of the largest borrowers of concessionary Asian Development Fund resources. The loans and technical assistance grants have supported all key sectors, including energy, transport, social infrastructure, agriculture, and natural resources. ADB has also supported eight private sector projects worth $\$ 242.18$ million, including the Meghnaghat Power Project-the first build-own-operate power project in the country-and Grameen Phone, which substantially expanded rural access to mobile phone services. In the late 1980s, ADB was primarily a lender for growth-promoting investment projects. There was also a growing emphasis on social infrastructure with focus on human development, gender equality, and poverty reduction. In line with the 1999 country operational strategy, ADB expanded its support into new areas in urban and rural infrastructure, and education to encompass decentralization and good governance. An array of successful projects illustrates the broad impact of ADB's assistance. With co financing from ADB, the World Bank, and the Government of Japan, for example, the Jamuna Bridge established an important land connection between the poorer northwest region of the country and the eastern half, which includes the capital, Dhaka, and Chittagong port in the southeast. The bridge has reduced transport costs, boosted trade, and increased labor migration. It has helped reduce poverty and increase economic and social opportunities, especially in the northwest. National estimates suggest that at least 1 million people were lifted out of poverty because of the positive impact of the bridge, which was opened to traffic in 1998.

Bangladesh: Cumulative ADB Lending as of 31 December 2010

\begin{tabular}{|l|l|l|l|}
\hline Sector & $\begin{array}{l}\text { Loans } \\
(\text { no. })\end{array}$ & $\begin{array}{l}\text { Amount } \\
(\$ \text { million })\end{array}$ & \% \\
\hline Agriculture and Natural Resources & 57 & $1,978.45$ & 16.30 \\
\hline Education & 18 & 897.16 & 7.39 \\
\hline Energy & 35 & $2,895.25$ & 23.86 \\
\hline Finance & 16 & 401.73 & 3.31 \\
\hline Health and Social Protection & 5 & 164.10 & 1.35 \\
\hline Industry and Trade & 16 & 564.80 & 4.65 \\
\hline Public Sector Management & 6 & 919.85 & 7.58 \\
\hline Transport and ICT & 35 & 2485.70 & 20.48 \\
\hline Water Supply and Other Municipal Infrastructure and services & 14 & 830.60 & 6.85 \\
\hline Multisector & & & \\
\hline Total & 10 & 996.70 & 8.21 \\
\hline
\end{tabular}

Source: ADB, 2011, Basic Statistics, 
Cofinancing operations enable ADB's financing partners-government or their agencies, multilateral financing institutions, and commercial organizations - to participate in the financing of ADB projects. The additional funds are provided in the form of grants, official or commercial loans, and syndications. As of yearend 2010, cumulative direct value-added cofinancing for Bangladesh amounted to $\$ 2.87$ billion for 30 investment projects and $\$ 60.4$ million for 74 technical assistance projects. In 2010, three projects received loan cofinancing: \$45.0 million from the Korea Export-Import Bank for the Natural Gas Access Improvement Project; \$10.0 million from International Fund for

\section{Bangladesh: Projects Cofinanced,1 January 2006-31 December 2010}

\begin{tabular}{|l|l|l|}
\hline Cofinancing & No of Project & Amounts (\$ million) \\
\hline Projects $*$ & 10 & $1,953.60$ \\
\hline Grants & 5 & 147.60 \\
\hline Officials Loans & 6 & 1806.00 \\
\hline Technical Assistance Grants & 6 & 3.25 \\
\hline
\end{tabular}

* A projects with more than one source of cofinancing is counted once.

Sources: ADB. 2011. Asian Development Outlook 2011. Manila;

From 1 January 1968 to 31 December 2010, consultants were involved in 11,643 contracts for ADB loan projects worth $\$ 4.63$ billion. During the same period, consultants from Bangladesh were involved in 408 contracts for ADB loan projects worth $\$ 92.61$ million. From 1 January 1968 to 31 December 2010, consultants were involved in 22,350 contracts for ADB technical assistance projects worth $\$ 3.15$ billion. During the same period, consultants from Bangladesh were involved in 575 contracts for ADB technical assistance projects worth \$41.26 million.

To help Bangladesh address the challenges of widespread poverty, unequal economic growth, severe infrastructure gaps, and major climate change impacts, IFC seeks to help create jobs, enhance incomes, build business skills and facilitate policy reforms. IFC supports the World Bank Group's Country Assistance Strategy for Bangladesh, focusing on private sector development and is equipped to contribute to several of the government's priorities.

IFC operations in Bangladesh focus on three strategic pillars: Inclusive growth; climate change; and Global integration. IFC delivers on these pillars through the various components of operations in Bangladesh:

IFC Investments - IFC provides debt, equity and guarantee products to private sector companies, with special emphasis on financing private infrastructure, energy, manufacturing and services, health, education, banks and capital markets. As of June 2010, our committed portfolio stood at over USD 169 million in projects that span a range of sectors including cement, banking, private equity funds, agribusiness and micro-finance. in projects that span a range of sectors including cement, banking, private equity funds, agribusiness and microfinance.

IFC Advisory Services - IFC supports private sector development to help create jobs, enhance incomes, build business skills, and facilitates policy reform. IFC advises governments on improving the environment that businesses operate in and shares knowledge and best practices on public-private partnerships in infrastructure. It supports the private sector on environmental and social sustainability, reaches out to small and medium enterprises (SMEs) through microfinance institutions and banks, and helps SMEs develop capacity, business skills, and strengthen value chains.

PPP Advisory - IFC advises governments of emerging economies by assisting them in structuring and implementing public private partnership transactions in power, ports, healthcare, education, etc.

SME Ventures - IFC works to strengthen the capacity of selected SMEs, thus promoting economic growth; increasing access to finance, especially risk capital for SMEs; and improving the enabling environment to foster growth of the SME sector.

South Asia Enterprise Development Facility (SEDF) - SEDF aims to create opportunities and improve lives. SEDF is managed by IFC, in partnership with the UK's Department for International 
Development and the Norwegian Agency for Development Co-operation. SEDF facilitates the growth of small and medium enterprises by helping to improve their access to finance through a supportive financial infrastructure, financial products development and strengthening of financial institutions; and providing business services to strengthen value chains. SEDF also helps businesses adapt to the impact of climate change. SEDF operates in Bangladesh, Bhutan, northeast India and Nepal.

Bangladesh Investment Climate Fund (BICF) - BICF provides advisory services aimed at improving the business operating environment in Bangladesh. BICF is managed by IFC, in partnership with the U.K Department for International Development and the European Union. Its objectives are consistent with the Bangladesh government's strategic vision for private sector development within its poverty reduction strategy. Government agencies and BICF - in close collaboration with the key stakeholders in Bangladesh - jointly design and implement programs to institute business friendly policies, laws and regulations, and strengthen the institutions that implement them.

Together, IFC operations in Bangladesh have a goal to spur inclusive economic growth, and contribute towards the reduction of poverty.

On the above discussion, it is clearly identify that International Financial Organizations especially IBRD, IDA, ADB and IFC have great contribution on foster economic growth of Bangladesh. They can play a vital role for improving financial condition, economic enhancement and social development of Bangladesh

\section{Project finance \& Economic growth}

Project finance can be defined as "the creation of a legally independent project company financed with equity from one or more sponsoring firms and non-recourse debt for the purpose of investing in a capital asset" (Esty, 2007). Project finance is generally used for new, stand-alone, complex projects with large risks and massive informational asymmetries. Nevertheless, sponsors' equity contributions are small and the bulk of the financing is provided in form of non-recourse, syndicated loan trenches. The lead banks become project insiders through working with the project sponsors during the initial screening and structuring phase and are responsible for funding the loan in the global syndicated loan market by attracting other banks to become members of a loan syndicate (Gatti et al., 2008). As these loans are non-recourse - e.g. they finance the project company with no or only limited support from the sponsors - the syndicate bears much of the project's business risk. Here lies one of the key comparative advantages of project finance: It allows the allocation of specific project risks (i.e., completion and operating risk, revenue and price risk, and the risk of political interference or expropriation) to those parties best able to manage them (Brealey et al., 1996). Thus, project finance comprises not only financial arrangements dominated by non-recourse debt funded in the global syndicated loan market but also a large set of contractual arrangements aimed at risk management. The important point is, however, that project finance still functions relatively well in the least developed countries (LDCs). Most other types of capital, such as FDI, are not very effective in substituting the market, making project finance an attractive choice for LDCs like Bangladesh.

The five main functions of a financial market are: (1) ex-ante information production and efficient allocation of capital, (2) ex-post monitoring of investments and exerting corporate governance, (3) facilitation of diversification and management of risk, (4) mobilization and pooling of savings and (5) facilitation of transactions (Levine, 1997. For each of the five functions, we will show how the structure of project finance allows it to substitute the domestic market and control transaction costs. 


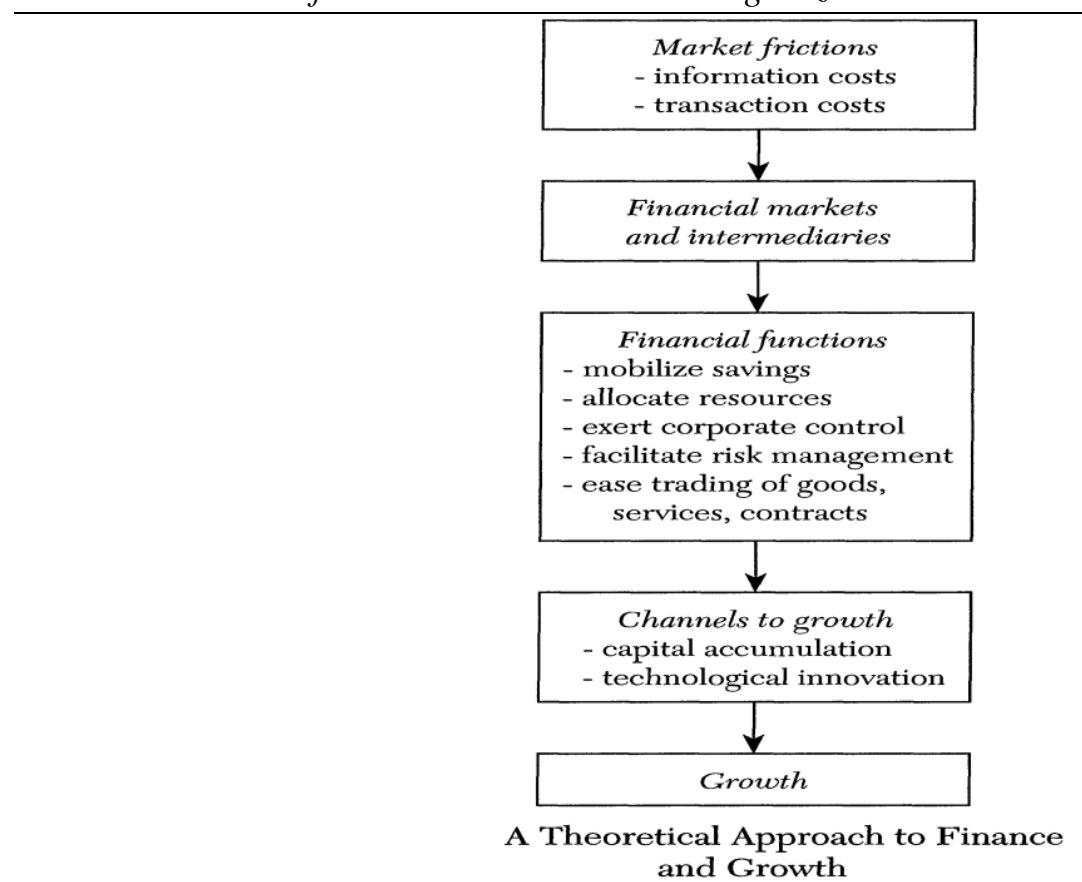

First consider transaction cost are common problem for possible investment and it arises from the lack of information and insufficient capital allocation. Project Finance helps to reduces these cost. Because project are financed through the syndicate of banks provides the majority of the funds and delegates the major screening and arranging tasks to the syndicate's lead banks. Again project finance can improve the efficiency of capital allocation that the main constraints for low income countries like Bangladesh. Project finance can overcome this problem by explicitly taken these financing needs into account and thus lead to a more effective allocation of capital.

Second Transaction cost also arises from the insufficient monitoring of investment and weak corporate governance. Project finance has several characteristics specifically designed to deal with agency problems. (1) Project finance lenders have a strong incentive to monitor due to high leverage and the non-recourse nature of their claim (Hainz andKleimeier, 2008). (2) The separation of the project from the sponsoring firm improves corporate governance as management is decentralized (3) Furthermore, the focus of the project company on a single investment reduces the risk of misallocation of funds regarding the initial investment (Brealey et al., 1996) while (4) the waste of free-cash flows during operation is reduced due to high leverage and the inclusion of a cash-waterfall as part of the contractual structure. (5) Finally, the extensive contractual structure increases transparency about the project, thereby improving governance. The flexibility of project finance also allows it to choose a form which best suits the market conditions. The involved parties are to some extent free to choose the law that regulates the project (Harries, 1989; Ahmed, 1999). A logical choice is the law of the country where the major tangible assets are located.

Third Project Finance is the preferred financing tool in countries with high political risk and cross sectional risk. Project Finance also cannot fully mitigate these risk, these are some characteristics it may at least reduce it. Because mostly International Financial Organizations provides project finance and try to mitigate risk by providing political \& commercial guarantees.

Fourth and fifth, consider the transaction costs arising from the inability to mobilize and pool savings and to facilitate transactions. In many cases the required sums for an investment are larger than those offered by a single investor. The inability of the market to pool savings and link them to investments can lead to severe financing constraints. Project finance is specifically designed to deal with large investments and the syndicates normally consist of large (international) banks. Therefore it should not be hindered much by the inability to pool savings, nor by the inability to facilitate transactions.

\section{Findings and Analysis}

7.1 It is revealed from the study that project finance through International Financial Organization can help foster growth on Economic Development of Bangladesh then other form of financing. 
Role of International Financial Organizations in the Economic Growth of Bangladesh.....

7.2 Project Success rate: Table\# 2 shows the project success rate of Asian Development Bank (ADB) in Bangladesh in different sectors and it shows total $59.09 \%$ that represent a high rate of success based on project completion report, project validation report and project evaluation report.

7.3 Growth rate of $(\%)$ of all dependant variables and Independent variables:Table 4 shows the growth pattern of all dependant variables and Independent variables from 2007 to 2011 . Almost all the year the growth rate is all variables are increasing trends.

7.4 Correlation Result Project Finance considered as Independent variables and GDP (current price), GDP per capita, Net Income and Government expenditure are considered as Dependent variable as well for further analysis. From this (Table-5,6,7) correlation analysis was carried out to find out the relationship among the variables.

Table 5,6, 7 shows that the correlation values between Project Finance and GDP are positively correlated with the values of .8079 (Table-5), .635 (Table-6) and .7567 (Table-7) which highly significant at $1 \%$ level of significant. In addition, GDP per capita, Net Income and Government expenditure are also positively correlated with GDP.

7.4 Impact of Macro economic factor Inflation Regression result of Inflation rate during the year 2006-2011 and growth rate of GDP per capita. Further a regression analysis is performed to identify the predictors of GDP as conceptualized in the model. A center-wise variable selection is used in the regression analysis and the following Table : 8 provides the summary measure of the model. In this model value of $\mathrm{R}^{2}$ denotes that $38.66 \%$ of the observed variability in GDP per capita can be explained by the different activities of inflation. The remaining $61.34 \%$ is not related which means that the rest $61.34 \%$ of the variation in GDP per capita is related to other variables which are depicted in the model. This variance is significant as indicated by the $\mathrm{F}$ value $(\mathrm{F}=2.52$; $\mathrm{P}$-Value $=.0418)$ and the examination of the model summary in conjunction with ANOVA indicates that the model explain the most possible combination combination of predictor variables that could contribute to the relationship with dependent variables.

In the Table: $8, \mathrm{t}$-Value for GDP per capita is highly significant at \% level. It indicates that with increasing level of GDP per capita; inflation will also increased 1.59 levels.

\section{Conclusion}

The study reveals the International Financial Organizations can play an important role through project finance for the development of Bangladesh. They contribute in the different projects for the economic enhancement of Bangladesh. Bangladesh is a developing country and not a self dependent. For the large-scale development, Bangladesh depends on different International Financial organization especially IBRD , IDA, IFC and ADB .Project Finance allows her to build the necessary projects to increase growth and development. It draws a greater volume of financing than under traditional schemes because risk are often spread among the various participants. Without project finance, many essential and life enhancing projects may have never been constructed in Bangladesh. In this study we examine the finance-growth nexus with specific focus on project finance. Based on the existing theoretical and empirical evidence on the impact of finance and growth, we hypothesize that project finance has the right features to stimulate growth.. We argue that project finance can adjust to less-than-favorable environments in least developed countries and might even substitute for the lack of institutional and financial development. Our results show that project finance through International Financial Organizations promotes growth in particular in low-income countries. Our evidence is consistent with the view that project finance has a superior ability to facility information production and good project governance. The structure of project finance leads to extensive and effective screening and project finance is also likely to flow to growth-enhancing industries. Overall, project finance is an effective tool to deal with high-risk environments.

\section{References:}

[1]. Ahmed, P.A., (1999). Project Finance In Developing Countries: IFC's Lessons

[2]. Of Experience. Washington DC: International Finance Corporation.

[3]. Brealey, R., I. Cooper, and M. Habib. (1996) Using project finance to fund infrastructure investments. Journal of Applied Corporate Finance, 9, 25- 38 .

[4]. $\quad$ Esty, B.C., (2007). An Overview of Project Finance \& Infrastructure Finance - 2006 Update. Boston: Harvard Business School Publishing.

[5]. Gatti, S., S. Kleimeier, W.L. Megginson and A. Steffanoni. (2008) Arranger certification in project finance. Working paper.

[6]. Hainz, C. and S. Kleimeier. (2008) Project finance as a risk-management tool in international syndicated lending. Working paper.

[7]. Harries, H. (1989). Project financing: avoiding six basic weaknesses. In N.

[8]. Horn (Ed.), The Law Of International Trade Finance, Leiden: Kluwer

[9]. Law and Taxation Publishers.

[10]. .Miller, M.H. (1998) Financial markets and economic growth. Journal of Applied Corporate Finance, 11, 8-14. 
Role of International Financial Organizations in the Economic Growth of Bangladesh.....

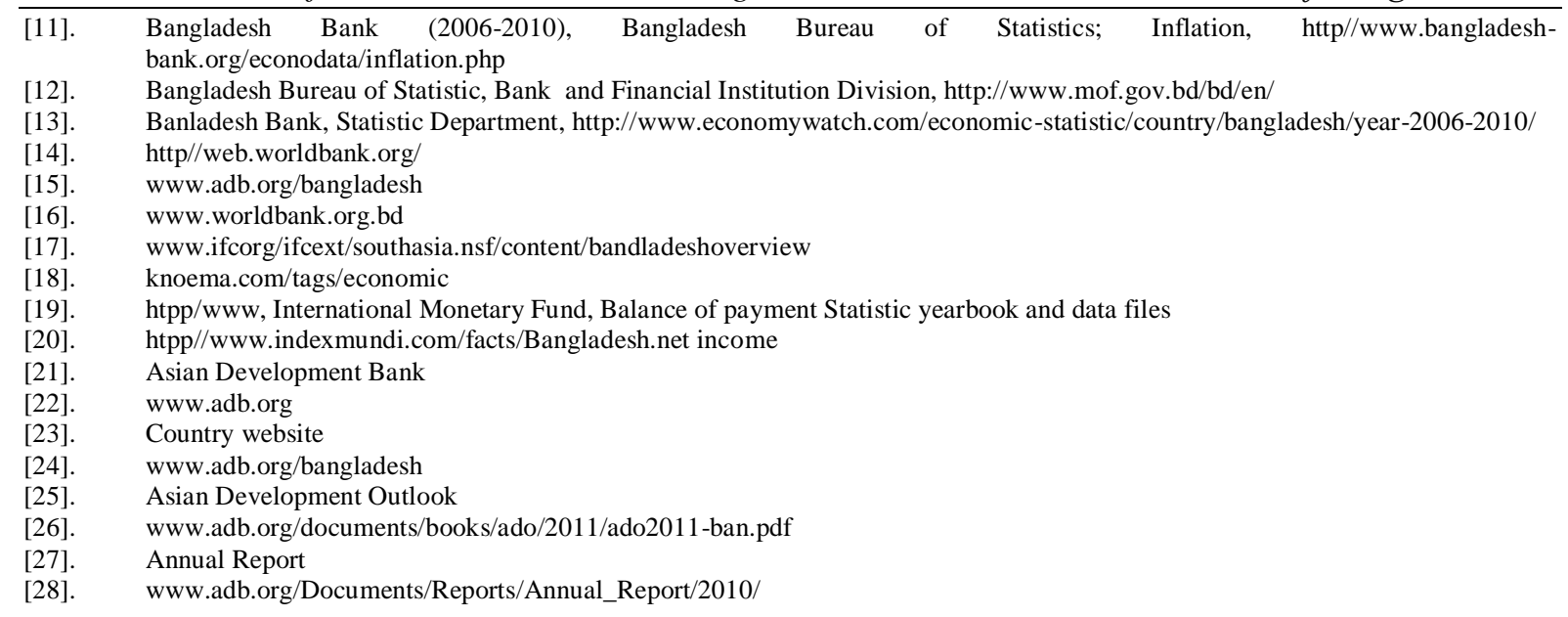

Appendix-1

Table-1.1 Project Volume of IBRD and IDA from 2006 to 2011

\begin{tabular}{|l|l|l|l|l|l|l|l|l|}
\hline Year & $\begin{array}{l}\text { Project } \\
\text { Finance } \\
\mathbf{( \$} \\
\text { million) }\end{array}$ & $\begin{array}{l}\text { GDP } \\
\text { (current } \\
\text { Price\$ } \\
\text { million) }\end{array}$ & $\begin{array}{l}\text { Project } \\
\text { Finance } \\
\mathbf{( \$} \\
\text { million) }\end{array}$ & $\begin{array}{l}\text { GDP } \\
\text { per } \\
\text { capita } \\
\mathbf{\$} \\
\text { million) }\end{array}$ & $\begin{array}{l}\text { Project } \\
\text { Finance } \\
\mathbf{\$} \\
\text { million }\end{array}$ & $\begin{array}{l}\text { Net Income } \\
(\$)\end{array}$ & $\begin{array}{l}\text { Project } \\
\text { Finance } \\
\mathbf{\$} \\
\text { million }\end{array}$ & $\begin{array}{l}\text { Government } \\
\text { Expenditure } \\
\mathbf{\$} \text { million) }\end{array}$ \\
\hline 2006 & 50 & 6520.4 & 50 & 419.42 & 50 & $840,697,500$ & 50 & 528.16 \\
\hline 2007 & 141.86 & 7396.90 & 141.86 & 468.89 & 141.86 & $967,940,600$ & 141.86 & 754.8 \\
\hline 2008 & 881.30 & 8446.20 & 881.30 & 527.89 & 881.30 & $1,018,927,000$ & 881.30 & 1034.6 \\
\hline 2009 & 273.20 & 9473.30 & 273.20 & 583.97 & 273.20 & $1,399,341,000$ & 273.20 & 1063.37 \\
\hline 2010 & 793.00 & 10491.90 & 793.00 & 637.91 & 793.00 & $1,406,364,000$ & 793.00 & 1205.73 \\
\hline 2011 & 2315.19 & 11538.70 & 2315.19 & 691.95 & 2315.19 & $1,652,400,000$ & 2315.19 & 1542.96 \\
\hline
\end{tabular}

Source: The world Bank : Project and Operation In Bangladesh \& Bangladesh Bank, Statistic Department

Table-1.2 Project Volume of ADB from 2006 to 2011

\begin{tabular}{|l|l|l|l|l|l|l|l|l|}
\hline Year & $\begin{array}{l}\text { Project } \\
\text { Finance } \\
\mathbf{\$} \\
\text { million) }\end{array}$ & $\begin{array}{l}\text { GDP } \\
\text { (current } \\
\text { Price\$ } \\
\text { million) }\end{array}$ & $\begin{array}{l}\text { Project } \\
\text { Finance } \\
\mathbf{\$} \text { million) }\end{array}$ & $\begin{array}{l}\text { GDP } \\
\text { per } \\
\text { capita } \\
\mathbf{\$} \\
\text { million) }\end{array}$ & $\begin{array}{l}\text { Project } \\
\text { Finance } \\
\mathbf{\$} \\
\text { million }\end{array}$ & $\begin{array}{l}\text { Net Income } \\
\mathbf{\$})\end{array}$ & $\begin{array}{l}\text { Project } \\
\text { Finance } \\
\mathbf{\$} \\
\text { million }\end{array}$ & $\begin{array}{l}\text { Government } \\
\text { Expenditure } \\
\mathbf{\$} \text { million) }\end{array}$ \\
\hline 2006 & 81.9 & 6520.4 & 81.9 & 419.42 & 81.9 & $840,697,500$ & 81.9 & 528.16 \\
\hline 2007 & 38.24 & 7396.90 & 38.24 & 468.89 & 38.24 & $967,940,600$ & 38.24 & 754.8 \\
\hline 2008 & 37.77 & 8446.20 & 37.77 & 527.89 & 37.77 & $1,018,927,000$ & 37.77 & 1034.6 \\
\hline 2009 & 394.25 & 9473.30 & 394.25 & 583.97 & $394 . .25$ & $1,399,341,000$ & $394 . .25$ & 1063.37 \\
\hline 2010 & 124.25 & 10491.90 & 124.25 & 637.91 & 124.25 & $1,406,364,000$ & 124.25 & 1205.73 \\
\hline 2011 & 320.075 & 11538.70 & 320.075 & 691.95 & 320.075 & $1,652,400,000$ & 320.075 & 1542.96 \\
\hline
\end{tabular}

Source: ADB: Project and Operation In Bangladesh \& Bangladesh Bank, Statistic Department

Table-1.3 Project Volume of IFC from 2006 to 2011

\begin{tabular}{|l|l|l|l|l|l|l|l|l|}
\hline Year & $\begin{array}{l}\text { Project } \\
\text { Finance } \\
\mathbf{\$} \\
\text { million) }\end{array}$ & $\begin{array}{l}\text { GDP } \\
\text { (current } \\
\text { Price\$ } \\
\text { million) }\end{array}$ & $\begin{array}{l}\text { Project } \\
\text { Finance } \\
\mathbf{\$} \\
\text { million) }\end{array}$ & $\begin{array}{l}\text { GDP } \\
\text { per } \\
\text { capita } \\
\mathbf{\$} \\
\text { million) }\end{array}$ & $\begin{array}{l}\text { Project } \\
\text { Finance } \\
\mathbf{\$} \\
\text { million }\end{array}$ & $\begin{array}{l}\text { Net Income } \\
(\$)\end{array}$ & $\begin{array}{l}\text { Project } \\
\text { Finance } \\
\mathbf{\$} \\
\text { million }\end{array}$ & $\begin{array}{l}\text { Government } \\
\text { Expenditure } \\
\mathbf{\$} \text { million) }\end{array}$ \\
\hline 2006 & 2.835 & 6520.4 & 2.835 & 419.42 & 2.835 & $840,697,500$ & 2.835 & 528.16 \\
\hline 2007 & 8 & 7396.90 & 8 & 468.89 & 8 & $967,940,600$ & 8 & 754.8 \\
\hline 2008 & 15 & 8446.20 & 15 & 527.89 & 15 & $1,018,927,000$ & 15 & 1034.6 \\
\hline 2009 & 10 & 9473.30 & 10 & 583.97 & 10 & $1,399,341,000$ & 10 & 1063.37 \\
\hline 2010 & 22 & 10491.90 & 22 & 637.91 & 22 & $1,406,364,000$ & 22 & 1205.73 \\
\hline 2011 & 112.41 & 11538.70 & 112.41 & 691.95 & 112.41 & $1,652,400,000$ & 112.41 & 1542.96 \\
\hline
\end{tabular}

Source: IFC : Project and Operation In Bangladesh \& Bangladesh Bank, Statistic Departmen 
Role of International Financial Organizations in the Economic Growth of Bangladesh.....

\begin{tabular}{|l|l|c|}
\hline \multicolumn{3}{c}{ Table-2 Bangladesh Project success rates } \\
\hline Sectors & $\%$ & $\begin{array}{l}\text { No of Rated } \\
\text { Projects/Program }\end{array}$ \\
\hline Agriculture and National Resources & 47.37 & 38 \\
\hline Education & 66.67 & 12 \\
\hline Energy & 76.92 & 13 \\
\hline Finance & 30.00 & 10 \\
\hline Health and Social Protection & 25.00 & 4 \\
\hline Industry and Trade & 60.00 & 5 \\
\hline Transport and ICT & 77.78 & 18 \\
\hline Water supply and other Municipal Infrastructure and services & 66.67 & 6 \\
\hline Multisector & 100.00 & 4 \\
\hline Total & $\mathbf{5 9 . 0 9}$ & $\mathbf{1 1 0}$ \\
\hline Year of Approval & & \\
\hline 1970s & 26.09 & 23 \\
\hline 1980s & 57.14 & 35 \\
\hline 1990s & 72.34 & 47 \\
\hline 2000s & 100 & 5 \\
\hline
\end{tabular}

Based on aggregate results of project/program completion reports (PCRs) PCR validation reports (PCRVRs) and project/program evaluation reports (PPERs) using PCRVR or PPER rating in all cases where PCR and PCRVR/ PPEr rating are avaible.

Sources: PCrs, PCRVRs and PPERs containing a rating circulated as of 31 December 2010

Table-3 Macro economic factor Inflation and growth rate of GDP per capita from 2006 to 2011

Inflation $(\%)$

6.77

9.11

8.9

5.43

8.235

7.64
GDP per capita(\%)
11.46
14.64
13.98
12.61
12.52
11.5

Source: Bangladesh Bank, Statistic Department

Table-4 Growth rate of $(\%)$ of all dependent variables and Independent variables

\begin{tabular}{|l|l|l|l|l|l|}
\hline Year & $\begin{array}{l}\text { Growth of Project } \\
\text { Finance (\%) }\end{array}$ & $\begin{array}{l}\text { Growth of } \\
\text { GDP(\%) }\end{array}$ & $\begin{array}{l}\text { Growth of } \\
\text { GDP per } \\
\text { capita(\%) }\end{array}$ & $\begin{array}{l}\text { Growth of } \\
\text { Net income } \\
(\%)\end{array}$ & $\begin{array}{l}\text { Growth of } \\
\text { Government } \\
\text { expenditure (\%) }\end{array}$ \\
\hline 2006 & -------- & 6.67 & 5.06 & 5.93 & \\
\hline 2007 & 25.57 & 13.44 & 11.80 & 15.14 & 42.91 \\
\hline 2008 & 28.35 & 14.19 & 12.58 & 5.27 & 37.07 \\
\hline 2009 & -27.47 & 12.16 & 10.63 & 37.33 & 2.78 \\
\hline 2010 & 38.64 & 10.75 & 9.24 & .50 & 13.39 \\
\hline 2011 & 33.13 & 9.98 & 8.47 & 17.45 & 27.91 \\
\hline
\end{tabular}

Source: Own study 
Role of International Financial Organizations in the Economic Growth of Bangladesh.....

Table 5: Correlation Matrix for IBRD and IDA: Correlation significant at the .01 level (two tailed)

\begin{tabular}{|c|c|c|c|c|c|c|c|c|}
\hline & $\begin{array}{l}\text { Project } \\
\text { Finance }\end{array}$ & GDP & $\begin{array}{l}\text { Project } \\
\text { Finance }\end{array}$ & $\begin{array}{l}\text { GDP per } \\
\text { capita }\end{array}$ & $\begin{array}{l}\text { Project } \\
\text { Finance }\end{array}$ & Net Income & $\begin{array}{l}\text { Project } \\
\text { Finance }\end{array}$ & $\begin{array}{l}\text { Government } \\
\text { Expenditure }\end{array}$ \\
\hline Project Finance & 1 & & & & & & & \\
\hline GDP & 0.807964619 & 1 & & & & & & \\
\hline Project Finance & 1 & 0.807964619 & 1 & & & & & \\
\hline GDP per capita & 0.80120937 & 0.999841293 & 0.80120937 & 1 & & & & \\
\hline Project Finance & 1 & 0.807964619 & 1 & 0.80120937 & 1 & & & \\
\hline Net Income & 0.742438882 & 0.972738696 & 0.7424388882 & 0.971866922 & 0.742438882 & 1 & & \\
\hline $\begin{array}{l}\text { Project Finance } \\
\text { Government }\end{array}$ & 1 & 0.807964619 & 1 & 0.80120937 & 1 & 0.742438882 & 1 & \\
\hline Expenditure & 0.882940172 & 0.976934242 & 0.882940172 & 0.976812206 & 0.882940172 & 0.929106284 & 0.882940172 & 1 \\
\hline
\end{tabular}

Table 6: Correlation Matrix for ADB: Correlation significant at the .01 level (two tailed)

\begin{tabular}{|c|c|c|c|c|c|c|c|c|}
\hline & $\begin{array}{l}\text { Project } \\
\text { Finance }\end{array}$ & GDP & $\begin{array}{l}\text { Project } \\
\text { Finance }\end{array}$ & $\begin{array}{l}\text { GDP per } \\
\text { capita }\end{array}$ & $\begin{array}{l}\text { Project } \\
\text { Finance }\end{array}$ & Net Income & $\begin{array}{l}\text { Project } \\
\text { Finance }\end{array}$ & $\begin{array}{l}\text { Government } \\
\text { Expenditure }\end{array}$ \\
\hline Project Finance & 1 & & & & & & & \\
\hline GDP & 0.635163 & 1 & & & & & & \\
\hline Project Finance & 1 & 0.635162651 & 1 & & & & & \\
\hline GDP per capita & 0.635481 & 0.999841352 & 0.635480794 & 1 & & & & \\
\hline Project Finance & 1 & 0.635162651 & 1 & 0.635480794 & 1 & & & \\
\hline Net Income & 0.781595 & 0.9727386996 & 0.781594618 & 0.9718628667 & 0.781594618 & 1 & & \\
\hline $\begin{array}{l}\text { Project Finance } \\
\text { Government }\end{array}$ & 1 & 0.635162651 & 1 & 0.635480794 & 1 & 0.781594618 & 1 & \\
\hline Expenditure & 0.577451 & 0.976934242 & 0.577450701 & 0.976813038 & 0.577450701 & 0.929106284 & 0.577450701 & 1 \\
\hline
\end{tabular}

Source: Own study

Table 7: Correlation Matrix for IFC : Correlation significant at the .01 level (two tailed)

\begin{tabular}{|c|c|c|c|c|c|c|c|c|}
\hline & $\begin{array}{l}\text { Project } \\
\text { Finance }\end{array}$ & GDP & $\begin{array}{l}\text { Project } \\
\text { Finance }\end{array}$ & $\begin{array}{l}\text { GDP per } \\
\text { capita }\end{array}$ & $\begin{array}{l}\text { Project } \\
\text { Finance }\end{array}$ & Net Income & Project Finance & Government Expenditure \\
\hline $\begin{array}{l}\text { Project } \\
\text { Finance }\end{array}$ & 1 & & & & & & & \\
\hline GDP & 0.756721631 & 1 & & & & & & \\
\hline Project & & & & & & & & \\
\hline $\begin{array}{l}\text { Finance } \\
\text { GDP per }\end{array}$ & 1 & 0.756721631 & 1 & & & & & \\
\hline $\begin{array}{l}\text { capita } \\
\text { Project }\end{array}$ & 0.746971407 & 0.999841293 & 0.746971407 & 1 & & & & \\
\hline Finance & 1 & 0.756721631 & 1 & 0.746971407 & 1 & & & \\
\hline $\begin{array}{l}\text { Net Income } \\
\text { Project }\end{array}$ & 0.747939588 & 0.972738696 & 0.747939588 & 0.971866922 & 0.747939588 & 1 & & \\
\hline $\begin{array}{l}\text { Finance } \\
\text { Government }\end{array}$ & 1 & 0.756721631 & 1 & 0.746971407 & 1 & 0.747939588 & 1 & \\
\hline Expenditure & 0.812480251 & 0.976934242 & 0.812480251 & 0.976812206 & 0.812480251 & 0.929106284 & 0.812480251 & 1 \\
\hline
\end{tabular}


Role of International Financial Organizations in the Economic Growth of Bangladesh..... SUMMARY OUTPUT

Table 8: Regression result of Micro economic force which may effect GDP per capita i.e. Inflation

\begin{tabular}{lr}
\hline \multicolumn{2}{c}{ Regression Statistics } \\
\hline Multiple R & 0.621768418 \\
& \\
RS.quare & 0.386595965 \\
Adjusted R & \\
S.quare & 0.233244956 \\
Standard Error & 1.133394487 \\
Observations & 6 \\
\hline
\end{tabular}

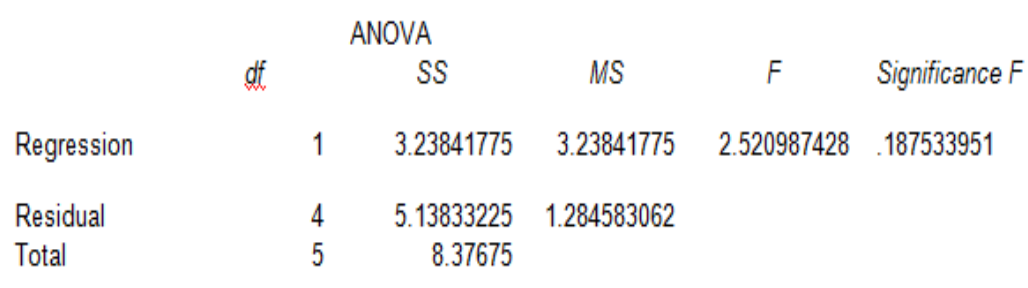

\begin{tabular}{|c|c|c|c|c|c|c|c|c|}
\hline & & Standard & & & & & & \\
\hline & Coefficients & Error & $t$ Stat & P-value & Lower 95\% & Upper 95\% & Lower $95.0 \%$ & Upper $95.0 \%$ \\
\hline Intercept & 8.35463206 & 2.828426911 & 2.953808715 & 0.041810759 & 0.501660007 & 16.20760411 & 0.501660007 & \\
\hline X Variable 1 & 0.576808238 & 0.363283869 & 1.587761767 & 0.187533951 & -0.431829482 & 1.585445958 & -0.431829482 & \\
\hline
\end{tabular}

Source: Own study 